Article

\title{
C- and N-Bearing Species in Reduced Fluids in the Simplified C-O-H-N System and in Natural Pelite at Upper Mantle P-T Conditions
}

\author{
Ivan Sokol ${ }^{1, *}$, Alexander Sokol ${ }^{1,2}$, Taras Bul'bak ${ }^{1}$, Andrey Nefyodov ${ }^{3}$, Pavel Zaikin ${ }^{3}$ \\ and Anatoly Tomilenko ${ }^{1}$ \\ 1 V.S. Sobolev Institute of Geology and Mineralogy, Siberian Branch of the Russian Academy of \\ Sciences (IGM SB RAS), 3, Koptyug ave., 630090 Novosibirsk, Russia; sokola@igm.nsc.ru (A.S.); \\ taras@igm.nsc.ru (T.B.); tomilen@igm.nsc.ru (A.T.) \\ 2 Novosibirsk State University, 2, Pirogov str., 630090 Novosibirsk, Russia \\ 3 N.N. Vorozhtsov Novosibirsk Institute of Organic Chemistry, Siberian Branch of the Russian Academy of \\ Sciences, 9, Lavrentiev ave., 630090 Novosibirsk, Russia; anefyodov@yandex.ru (A.N.); \\ zaikin@gmail.com (P.Z.) \\ * Correspondence: isokol0x5a@gmail.com
}

Received: 26 September 2019; Accepted: 10 November 2019; Published: 18 November 2019

check for updates

\begin{abstract}
C}$ - and $\mathrm{N}$-bearing species in reduced fluids weree studied experimentally in $\mathrm{C}-\mathrm{O}-\mathrm{H}-\mathrm{N}$ and muscovite-C-O-H-N systems and in natural carbonate-bearing samples at mantle $P-T$ parameters. The experiments reproduced three types of reactions leading to formation of hydrocarbons (HCs) at 3.8-7.8 GPa and $800-1400{ }^{\circ} \mathrm{C}$ and at hydrogen fugacity $\left(f \mathrm{H}_{2}\right)$ buffered by the $\mathrm{Fe}-\mathrm{FeO}(\mathrm{IW})+$ $\mathrm{H}_{2} \mathrm{O}$ or $\mathrm{Mo}-\mathrm{MoO}_{2}(\mathrm{MMO})+\mathrm{H}_{2} \mathrm{O}$ equilibria: (i) Thermal destruction of organic matter during its subduction into the mantle (with an example of docosane), (ii) hydrogenation of graphite upon interaction with $\mathrm{H}_{2}$-enriched fluids, and (iii) hydrogenation of carbonates and products of their reduction in metamorphic clayey rocks. The obtained quenched fluids analyzed after the runs by gas chromatography-mass spectrometry (GC-MS) and electronic ionization mass-spectrometry (HR-MS) contain $\mathrm{CH}_{4}$ and $\mathrm{C}_{2} \mathrm{H}_{6}$ as main carbon species. The concentrations of $\mathrm{C}_{2}-\mathrm{C}_{4}$ alkanes in the fluids increase as the pressure and temperature increase from 3.8 to $7.8 \mathrm{GPa}$ and from 800 to $1400{ }^{\circ} \mathrm{C}$, respectively. The fluid equilibrated with the muscovite-garnet-omphacite-kyanite-rutile \pm coesite assemblage consists of 50-80 rel.\% $\mathrm{H}_{2} \mathrm{O}$ and $15-40$ rel.\% alkanes $\left(\mathrm{C}_{1}>\mathrm{C}_{2}>\mathrm{C}_{3}>\mathrm{C}_{4}\right)$. Main N-bearing species are ammonia $\left(\mathrm{NH}_{3}\right)$ in the $\mathrm{C}-\mathrm{O}-\mathrm{H}-\mathrm{N}$ and muscovite- $\mathrm{C}-\mathrm{O}-\mathrm{H}-\mathrm{N}$ systems or methanimine $\left(\mathrm{CH}_{3} \mathrm{~N}\right)$ in the fluid derived from the samples of natural pelitic rocks. Nitrogen comes either from air or melamine $\left(\mathrm{C}_{3} \mathrm{H}_{6} \mathrm{~N}_{6}\right)$ in model systems or from $\mathrm{NH}_{4}{ }^{+}$in the runs with natural samples. The formula $\mathrm{CH}_{3} \mathrm{~N}$ in the quenched fluid of the $\mathrm{C}-\mathrm{O}-\mathrm{H}-\mathrm{N}$ system is confirmed by HR-MS. The impossibility of $\mathrm{CH}_{3} \mathrm{~N}$ incorporation into K-bearing silicates because of a big $\mathrm{CH}_{3} \mathrm{NH}^{+}$cation may limit the solubility of $\mathrm{N}$ in silicates at low $f \mathrm{O}_{2}$ and hence may substantially influence the mantle cycle of nitrogen. Thus, subduction of slabs containing carbonates, organic matter, and N-bearing minerals into strongly reduced mantle may induce the formation of fluids enriched in $\mathrm{H}_{2} \mathrm{O}$, light alkanes, $\mathrm{NH}_{3}$, and $\mathrm{CH}_{3} \mathrm{~N}$. The presence of these species must be critical for the deep cycles of carbon, nitrogen, and hydrogen.
\end{abstract}

Keywords: mantle; subduction; pelite; fluid; hydrocarbons; methanimine; deep carbon cycle; deep nitrogen cycle

\section{Introduction}

Hydrocarbons (HCs) and ammonia have been important agents in the Earth's carbon and nitrogen cycles. Their stability in different tectonic settings in the course of geodynamic evolution has been 
responsible for the habitability of the planet, the amounts of carbon and nitrogen migrating in fluids, and the formation of diamonds [1-7].

Much recent progress in experiments at mantle pressures and temperatures allows reconstructing the compositions of hydrocarbon fluids that form in different ways: By thermal decomposition of higher alkanes, aromatic compounds, and fatty carboxylic acids [8-11]; reaction of $\mathrm{CO}, \mathrm{CO}_{2}$, and carbonate with $\mathrm{FeO}$ and $\mathrm{H}_{2} \mathrm{O}$; or hydrogenation of carbon [7,12-20]. Thermodynamic calculations and experimental data indicate that organic species, such as light alkanes, acids, and salts, e.g. acetic acid and acetates, can be stable in the silicate mantle under the appropriate redox conditions [4,7,10,12-17,19-22]. Specifically, light alkanes were found out [22] to be stable in a wide range of redox conditions in the presence of a lherzolitic mineral assemblage at 5.5-7.8 GPa and $1150-1350{ }^{\circ} \mathrm{C}$. The discovery of hydrocarbons in diamonds from the mantle and in crustal alkaline rocks $[5,17,23-27]$ supports this conclusion.

Large amounts of volatiles (mainly in carbonates and hydrous minerals) can penetrate into the mantle with sinking slabs that consist of sediments, altered oceanic crust, and partially serpentinized lithospheric mantle $[28,29]$. Features of $\mathrm{HC}$ generation at the account of slab-derived $\mathrm{H}_{2} \mathrm{O}$ and iron-bearing carbonates at $f \mathrm{O}_{2}$ near the $\mathrm{FeO}-\mathrm{Fe}_{3} \mathrm{O}_{4}(\mathrm{WM})$ equilibrium, i.e., in relatively oxidized conditions, were discussed in several publications $[7,12,13,16,17]$. However, little is known about the formation of HCs with participation of metamorphic mudrocks (pelites) subducted to mantle depths at $f \mathrm{O}_{2}$ near the $\mathrm{Fe}-\mathrm{FeO}$ (IW) buffer, where metal phases become stable. The first study of this kind belongs to Kucherov et al. [14]. The importance of the process was highlighted by Smith et al. [5] who discovered sublithospheric diamonds with metal phase inclusions and a thin fluid jacket of $\mathrm{CH}_{4}$ and $\mathrm{H}_{2}$. The abundance of CaSi-perovskite and Cr-poor majoritic garnets supports the formation of diamond in slabs within the transition zone or in the uppermost lower mantle. Our recent study [19] of HC generation by hydrogenation of different carbon sources in the presence of metal phases is another step forward in this field.

Ammonia $\left(\mathrm{NH}_{3}\right)$ has received most of attention among N-bearing species in reduced fluids since nitrogen is transported to mantle depths mostly in the form of $\mathrm{NH}_{4}^{+}$that substitutes for $\mathrm{K}^{+}$ in silicates from subducted sediments $[3,30,31]$. The mechanism is maintained by the presence of K-bearing minerals (micas, K-hollandite, K-cymrite) in pelitic slab material $[3,32,33]$ and depends on $\mathrm{NH}_{3} / \mathrm{NH}_{4}{ }^{+}$ratios in the equilibrated fluid [34]. The possibility for nitrogen to travel with slabs to upper mantle depths is supported by its rather high contents in diamonds, such as those from ultra-high-pressure metamorphic rocks of the Kokchetav complex [35]. The stability of $\mathrm{NH}_{3}$ in mantle fluids depends on oxygen fugacity. Studies of nitrogen speciation in mantle and crustal $\mathrm{N}-\mathrm{H}-\mathrm{O}$ fluids at $600-1400{ }^{\circ} \mathrm{C}$ and 2-35 kbar by Li and Keppler [36] showed that $\mathrm{NH}_{3}$ can coexist with mantle minerals in aqueous fluids only at strongly reduced conditions close to $\mathrm{Fe}-\mathrm{FeO}$ buffer, whereas $\mathrm{N}_{2}$ is the dominant nitrogen specie of the oxidized shallow upper mantle fluids. Yet, Li and Keppler [36] have not analyzed the stability of $\mathrm{N}$ - and C-bearing fluid species as nitrogen depots. Later we $[10,22,37]$ investigated the formation and stability of ammonia in fluid phases of $\mathrm{C}-\mathrm{O}-\mathrm{H}-\mathrm{N}, \mathrm{Fe}-\mathrm{C}-\mathrm{O}-\mathrm{H}-\mathrm{N}$, and lherzolite-C-O-H-N model systems at pressures from 5.5 to $7.8 \mathrm{GPa}$ and temperatures from 1100 to $1400{ }^{\circ} \mathrm{C}$. Ammonia turned out to predominate in quenched fluids synthesized at high $f \mathrm{H}_{2}$ buffered externally by $\mathrm{Fe}-\mathrm{FeO}$ (IW) $+\mathrm{H}_{2} \mathrm{O}$ or Mo- $\mathrm{MoO}_{2}$ (MMO) $+\mathrm{H}_{2} \mathrm{O}$ equilibria and $f \mathrm{O}_{2}$ near the IW buffer. However, the $\mathrm{N}_{2} /\left(\mathrm{N}_{2}+\mathrm{NH}_{3}\right)$ ratio exceeded 0.5 at $f \mathrm{O}_{2}$ values of $\mathrm{IW}+0.7 \log$ units and tended to unity in all fluids synthesized at progressively more oxidized conditions, including fluids equilibrated with magnesite-bearing lherzolite. On the other hand, a compound with a mass-to-charge ratio of $\mathrm{m} / \mathrm{z}=29$ was the main $\mathrm{N}$-bearing species in quenched $\mathrm{N}$-poor reduced $\mathrm{C}-\mathrm{O}-\mathrm{H}-\mathrm{N}$ fluids synthesized at $6.3 \mathrm{GPa}$ and $1100-1400{ }^{\circ} \mathrm{C}$ [38]. Judging by the short retention time, this signal represents a low molecular weight compound, namely, methanimine $\left(\mathrm{CH}_{3} \mathrm{~N}\right)$. To exclude a possibility of this signal being an isotope signal of ${ }^{14} \mathrm{~N}^{15} \mathrm{~N}$ or a signal of a radical fragment, the identification of $\mathrm{CH}_{3} \mathrm{~N}$ was supplemented by the measuring of the exact molecular weight of the $\left[\mathrm{M}^{+}\right]=29$ compound and comparing its full mass spectrum with published data. 
This study focuses on C- and N-bearing species in reduced fluids synthesized at 3.8-7.8 GPa and $800-1400{ }^{\circ} \mathrm{C}$ in the model systems of $\mathrm{C}-\mathrm{O}-\mathrm{H}-\mathrm{N}$ and muscovite-C-O-H-N and in charges with natural samples of pelite (Maykop Fm. shale, Russia) and N-bearing mica schist (Polar Ural, Russia) which represented carbonate-bearing slab material subducted to mantle depths. Since methanimine can affect the nitrogen and carbon mantle cycles, it was important to check whether it can exist in hydrocarbon-rich fluids that form during hot subduction. Therefore, special efforts were made to identify methanimine in quenched fluids obtained in the experimental systems at $6.3 \mathrm{GPa}$ and $1000-1200{ }^{\circ} \mathrm{C}$.

\section{Materials and Methods}

\subsection{Materials}

The features of $\mathrm{C}$ - and N-bearing species in fluids obtained in synthetic systems were studied using pure natural graphite $(99.99 \% \mathrm{C})$ pre-dried at $110{ }^{\circ} \mathrm{C}$ for at least 30 days and chemical grade synthetic diamond (ACM-20/14, 14-20 $\mu \mathrm{m})$ pre-annealed in air at $700{ }^{\circ} \mathrm{C}$ for $1 \mathrm{~h}$ as fluid-generating carbon sources. The starting mixtures also contained at least $99 \%$ purity docosane $\left(\mathrm{C}_{22} \mathrm{H}_{46}\right)$, melamine $\left(\mathrm{C}_{3} \mathrm{H}_{6} \mathrm{~N}_{6}\right)$, distilled water, and silver oxalate $\left(\mathrm{Ag}_{2} \mathrm{C}_{2} \mathrm{O}_{4}\right)$ (Table 1). Air was the only $\mathrm{N}$ source in melamine-free samples. Pycnometer testing revealed about 39 vol.\% of air in the capsules. Pre-dried graphite contained $700 \mathrm{ppm} \mathrm{CO}_{2}$ and $700 \mathrm{ppm} \mathrm{H}_{2} \mathrm{O}$. Distilled water was added to capsules with a microsyringe to $\pm 0.2 \mathrm{mg}$ accuracy. The capsules were sealed by arc-welding prior to experiments. The capsule assembly details were described in our previous publications $[10,19,20,38]$.

The starting materials used to study C- and N-bearing species in the fluids equilibrated with muscovite (Table 2), natural Maykop Fm. shale (Taman Peninsula, Russia; hereafter referred to as pelite) [39], and N-rich quartz-muscovite-chlorite schist (hereafter referred to as mica schist) (Polar Ural, Russia), as well as melamine or distilled water. The mica schist, with up to $266 \mathrm{ppm} \mathrm{NH}_{4}$ [40], was metamorphosed at $0.2 \mathrm{GPa}$ and 570 to $580^{\circ} \mathrm{C}$. As shown by the thermogravimetric (TG) analysis, it contained up to $0.91 \mathrm{wt}$ \% carbonate $\mathrm{CO}_{2}$ and $2.21 \mathrm{wt}$. $\% \mathrm{H}_{2} \mathrm{O}$ in total. The pelite sample contained 2.0 wt. \% calcite and $1.7 \mathrm{wt}$. \% siderite, according to the quantitative X-ray diffraction (QXRD) data [39] and 1.87 wt. $\% \mathrm{CO}_{2}, 2.05 \mathrm{wt}$. \% of adsorbed $\mathrm{H}_{2} \mathrm{O}$, and $3.33 \mathrm{wt}$. \% of hydroxyl according to the TG analysis. The content of nitrogen in the pelite sample was not specially analyzed, but it may be from 424 to $2382 \mathrm{ppm}[41,42]$. The pelite and mica schist samples exposed to the experimental $P-T$ conditions can be appropriate analogues of metasediments subducted to mantle depths judging by what is known from the literature $[6,28,43,44]$. 
Table 1. Compositions of samples and run conditions.

\begin{tabular}{|c|c|c|c|c|c|c|c|c|c|c|c|c|c|c|}
\hline \multirow{2}{*}{ Run\# } & \multirow{2}{*}{ P (GPa) } & \multirow{2}{*}{$\mathrm{T}\left({ }^{\circ} \mathrm{C}\right)$} & \multirow{2}{*}{ Buffer } & \multirow{2}{*}{ Capsule } & \multirow{2}{*}{$\tau(\mathrm{h})$} & \multicolumn{9}{|c|}{ Compositions of Samples, mg } \\
\hline & & & & & & $\mathrm{Gr}$ & Ms & Pelite & Mica Schist & $\mathrm{C}_{3} \mathrm{H}_{6} \mathrm{~N}_{6}$ & $\mathrm{H}_{2} \mathrm{O}$ & $\mathrm{C}_{22} \mathrm{H}_{46}$ & $\mathrm{Ag}_{2} \mathrm{C}_{2} \mathrm{O}_{4}$ & $\mathrm{Dm}$ \\
\hline 1668_2_1 & 5.5 & 1150 & - & $\mathrm{Pt}$ & 10 & 10.1 & - & - & - & - & - & - & - & - \\
\hline 1906_2_1 & 6.3 & 1400 & - & $\mathrm{Pt}$ & 0.33 & 8.4 & - & - & - & - & - & - & - & - \\
\hline 1969_2_1 & 5.5 & 1150 & MMO & $\mathrm{Pt}$ & 40 & 8.5 & & - & - & - & - & 0.8 & - & - \\
\hline 996_5_6 & 5.5 & 1200 & $\mathrm{MMO}$ & $\mathrm{Pt}$ & 10 & 9.8 & & - & - & - & - & & 0.5 & - \\
\hline 2107_2_3* & 6.3 & 1200 & $\mathrm{MMO}$ & $\mathrm{Au}$ & 10 & 9.5 & & - & - & - & - & 0.5 & - & - \\
\hline $2107 \_2 \_4$ * & 6.3 & 1200 & $\mathrm{MMO}$ & $\mathrm{Au}$ & 10 & 10.8 & - & - & - & - & - & - & - & - \\
\hline 1942_2_2 & 7.8 & 1350 & $\mathrm{MMO}$ & $\mathrm{Pt}$ & 10 & 9.7 & - & - & - & - & - & - & - & - \\
\hline 1975_2_1 & 7.8 & 1350 & IW & $\mathrm{Pt}$ & 10 & 16.4 & - & - & - & - & - & - & - & - \\
\hline 1670_2_1 & 7.8 & 1350 & IW & $\mathrm{Pt}$ & 10 & 11.4 & - & - & - & - & - & - & - & - \\
\hline 1670_2_3 & 7.8 & 1350 & IW & $\mathrm{Pt}$ & 10 & - & & - & - & - & - & - & - & 8.1 \\
\hline 1695_1_4 & 3.8 & 800 & MMO & $\mathrm{Au}$ & 40 & - & 8.5 & - & - & 0.5 & & - & - & - \\
\hline 1981_2_6 & 5.5 & 1000 & MMO & $\mathrm{Au}$ & 40 & 2.1 & 8.3 & - & - & - & 0.9 & - & - & - \\
\hline 2093_2_1 & 6.3 & 1000 & MMO & $\mathrm{Au}$ & 60 & - & & 9.8 & - & - & - & - & - & - \\
\hline 2093_2_3 & 6.3 & 1000 & $\mathrm{MMO}$ & $\mathrm{Au}$ & 60 & - & & - & 10.9 & - & - & - & - & - \\
\hline
\end{tabular}

* samples used for high resolution mass-spectrometry. $\mathrm{Gr}=$ graphite; $\mathrm{Dm}=$ diamond; Ms = muscovite; natural samples are Maykop Fm. shale (Russia) and mica schist (Polar Ural, Russia); $\mathrm{C}_{3} \mathrm{H}_{6} \mathrm{~N}_{6}$ is melamine; $\mathrm{C}_{22} \mathrm{H}_{46}$ is docosane; $\mathrm{Ag}_{2} \mathrm{C}_{2} \mathrm{O}_{4}$ is silver oxalate; $\mathrm{IW}=\mathrm{Fe}-\mathrm{FeO} ; \mathrm{MMO}=\mathrm{Mo}-\mathrm{MoO}_{2}$. 
Table 2. Major-element compositions of starting muscovite, pelite and mica schist (wt. \%).

\begin{tabular}{cccc}
\hline Muscovite & $\begin{array}{c}\text { Pelite }^{*} \\
\text { (Maykop Fm. Russia) }\end{array}$ & $\begin{array}{c}\text { Mica Schist } \\
\text { (Polar Ural, Russia) }\end{array}$ \\
\hline $\mathrm{SiO}_{2}$ & 46.3 & 53.9 & 48.4 \\
$\mathrm{TiO}_{2}$ & 0.1 & 0.8 & 1.4 \\
$\mathrm{Al}_{2} \mathrm{O}_{3}$ & 34.6 & 16.3 & 22.4 \\
$\mathrm{FeO}$ & 1.5 & 7.3 & 10.8 \\
$\mathrm{MnO}$ & 0.1 & 0.1 & 0.2 \\
$\mathrm{MgO}$ & 0.8 & 3.2 & 4.3 \\
$\mathrm{CaO}$ & - & 1.8 & 0.6 \\
$\mathrm{Na} 2$ & 0.5 & 1.3 & 3.1 \\
$\mathrm{~K}_{2} \mathrm{O}$ & 10.8 & 2.9 & 3.3 \\
$\mathrm{P}_{2} \mathrm{O}$ & - & 0.1 & 0.3 \\
$\mathrm{BaO}$ & 0.4 & - & 0.1 \\
$\mathrm{LOI}$ & - & 11.1 & 4.1 \\
$\mathrm{Total}$ & 95.1 & 99.0 & 99.2 \\
\hline
\end{tabular}

* contains 2.0 wt. \% calcite and 1.7 wt. \% siderite according to QXRD; 1.87 wt. \% $\mathrm{CO}_{2}, 2.05$ wt. \% adsorbed $\mathrm{H}_{2} \mathrm{O}$, and 3.33 wt. \% water as $\mathrm{OH}$ according to TG; ${ }^{* *}$ contains 0.91 wt. \% carbonate $\mathrm{CO} 2$ and total 2.21 wt. \% $\mathrm{H} 2 \mathrm{O}$ according to TG.

\subsection{Methods}

Experiments at 3.8, 5.5, 6.3, and 7.8 GPa were carried out in a split-sphere multi-anvil high-pressure apparatus [45]. Pressure was calibrated by recording the change in the resistance of Bi at $2.55 \mathrm{GPa}$ and $\mathrm{PbSe}$ at 4.0 and $6.8 \mathrm{GPa}$ at room temperature and by bracketing the quartz-coesite and the graphite-diamond equilibrium at 3.8, 5.5, 6.3, and 7.8 GPa and high temperatures. The second phase transition of Bi occurring at 7.7 GPa at ambient temperature was not used for calibration since the information obtained from other systems is sufficient. Temperature was monitored in each experiment using a $\mathrm{PtRh}_{6} / \mathrm{PtRh}_{30}$ thermocouple calibrated at $6.3 \mathrm{GPa}$ and $7.8 \mathrm{GPa}$ using the melting points of $\mathrm{Al}$, $\mathrm{Ag}, \mathrm{Ni}$ and Pt. Pressure and temperature were measured to an accuracy of $\pm 0.1 \mathrm{GPa}$ and $\pm 20^{\circ} \mathrm{C}[45,46]$. The charges were quenched under isobaric conditions at a rate of $200 \mathrm{deg} / \mathrm{s}$. As shown by special studies of the effect of cooling rate on fluid compositions [36,38], cooling from $800-1400{ }^{\circ} \mathrm{C}$ to room temperature at $200 \mathrm{deg} / \mathrm{s}$ can provide quenching and furnish reliable evidence of the fluid compositions at the applied $P-T$ conditions.

The run durations from 2 to $60 \mathrm{~h}$ (Table 1) were chosen because equilibrium fluids rich in hydrocarbons (HC) and N-bearing species in the $\mathrm{C}-\mathrm{O}-\mathrm{H}-\mathrm{N}$ experimental system at $6.3 \mathrm{GPa}$ and $1100-1400{ }^{\circ} \mathrm{C}$ form in at least two hours [10,38]; one $1400{ }^{\circ} \mathrm{C}$ run was as short as $20 \mathrm{~min}$. Long $40-60 \mathrm{~h}$ durations were used to bring the fluid-bearing silicate systems close to the equilibrium.

Hydrogen fugacity was buffered by the $\mathrm{Fe}-\mathrm{FeO}(\mathrm{IW})+\mathrm{H}_{2} \mathrm{O}$ and $\mathrm{Mo}-\mathrm{MoO}_{2}(\mathrm{MMO})+\mathrm{H}_{2} \mathrm{O}$ equilibria using a modified double-capsule technique, with inner Pt or Au capsules placed inside thick-walled Fe or Mo outer capsules with talc insulation [9]. Our previous experiments at 6.3 GPa and $1150-1400{ }^{\circ} \mathrm{C}[18,22]$ showed that $f \mathrm{H}_{2}$ buffering can maintain invariable compositions of $\mathrm{HC}$ and $\mathrm{C} / \mathrm{H}$ ratios in fluids as the run duration increased from $1 \mathrm{~min}$ to $>40 \mathrm{~h}$ with this technique, thus proving its workability at the applied $P-T-\tau$ parameters. For more details of the double-capsule technique, see [47]. As we calculated earlier for quenched $\mathrm{C}-\mathrm{O}-\mathrm{H}-\mathrm{N}$ fluids [10], their $f \mathrm{O}_{2}$ may generally vary from $\log f \mathrm{O}_{2} \Delta \mathrm{IW}-2.5$ to $\log f \mathrm{O}_{2} \Delta \mathrm{IW}+2.5$ ( $\Delta \mathrm{IW}$ is the logarithmic difference between experimental $f \mathrm{O}_{2}$ and that imposed by the coexistence of iron and wüstite) depending on the initial $\mathrm{H}_{2} \mathrm{O}$ contents in the charge and the selected IW or MMO buffers for $f \mathrm{H}_{2}$. Note that the MMO buffer is slightly more oxidized $\left(\log f \mathrm{O}_{2} \Delta \mathrm{IW}+1\right)$ [9]. In the absence of an external $f \mathrm{H}_{2}$ buffer, $f \mathrm{O}_{2}$ in samples was slightly higher than $\Delta \mathrm{IW}+2[10]$. 


\subsection{Analytical Techniques}

After quenching and retrieval from the high-pressure cells, the Pt capsules were placed into a crush cell connected on-line to a gas chromatograph before the analytical column. They were heated at $120-130{ }^{\circ} \mathrm{C}$ in a stream of carrier gas $(99.9999 \%$ pure He) for $90 \mathrm{~min}$ to clean the surface from adsorbed gases and to evaporate water for further analysis of the released gases. The pre-heating duration depended on the rate of gas desorption and was analyzed on-line. Blank pre-heating runs showed neither speciation nor concentration changes in volatiles in the capsules at $120-130{ }^{\circ} \mathrm{C}$. The capsules that did not sustain heating were excluded from analysis. The gas mixture extracted from capsules by piercing was analyzed by gas chromatography and mass spectrometry using a Thermo Scientific Focus GS/DSQ II Series single quadrupole gas chromatograph-mass analyzer at the V.S. Sobolev Institute of Geology and Mineralogy. The relative concentrations (rel.\%) of volatile components in the studied mixture were obtained by normalization: The total area of all chromatographic peaks was normalized to $100 \%$, and the area of an individual component defined its proportion in the mixture. The normalization quality was checked against external standards [10]. The concentration ranges of alkanes during the calibration were the same as in the run products. Analytical uncertainty was below $5 \%$ for $\mathrm{C}_{1}-\mathrm{C}_{4}$ alkanes and less than $10 \%$ for $\mathrm{H}_{2} \mathrm{O}, \mathrm{NH}_{3}$, and $\mathrm{CO}_{2}$ (determined in the range from $12.5 \mathrm{pptv}$ to $12.5 \mathrm{ppbv}$ and expressed as precision), or even $<5 \%$ in most cases. For details of the GC-MS method, see [10].

Exact masses of methanimine were determined on a Thermo Fisher Scientific Double Focusing System (DFS) Magnetic Sector high resolution mass-spectrometer at the N. Vorozhtsov Institute of Organic Chemistry (Novosibirsk). The operation conditions were: $70 \mathrm{eV}$ electron ionization and $200^{\circ} \mathrm{C}$ ion source temperature. The capsules with mixtures of volatiles were placed into a specially modified inlet for the mass calibration standard, which allowed capsule opening with a needle inside the volume intended for calibration. The inlet system was maintained at $200{ }^{\circ} \mathrm{C}$. The DFS mass-spectrometer was calibrated with respect to the standard lines of perfluorokerosene (PFK) prior to measurements. The exact masses of methanimine ions were measured relative to the mass lines of known particles $\left(\mathrm{CN}^{+}, \mathrm{HCN}^{+}\right)$.

In the end of the experiments, the recovered silicate samples were cleaned and mounted in epoxy resin. After the polymerization of resin, the samples were polished under kerosene, without the use of water (final stage $1 \mu \mathrm{m} \mathrm{Al}_{2} \mathrm{O}_{3}$ ) and examined on a Tescan MIRA $3 \mathrm{LMU}$ scanning electron microscope (SEM). The solid phase compositions were analyzed using the Tescan MIRA 3 LMU scanning electron microscope coupled with an INCA EDS 450 microanalysis system with an Oxford Instruments liquid nitrogen-free Large Area EDS X-Max-80 Silicon Drift Detector. The instruments were operated at an accelerating voltage of $20 \mathrm{keV}$, a beam current of $1 \mathrm{nA}$, and a spot size of $\sim 10 \mathrm{~nm}$; the count time for spectra acquisition was $20 \mathrm{~s}$. The EDS spectra were optimized for quantification using the standard XPP procedure built into the INCA Energy 450 software. The TG analyses were accomplished according to the method published by Dementyev et al. [48].

\section{Results}

The fluid phase was obtained in four runs from charges containing other solid phases besides graphite (see Table 3 for their representative analyses). Recrystallization of muscovite was observed in all runs of muscovite-C-O-H-N systems. The newly formed muscovite gained silica which increased from 3.12 to $3.27 \mathrm{apfu} \mathrm{Si}$ upon the temperature and the pressure change from $800{ }^{\circ} \mathrm{C}$ to $1000{ }^{\circ} \mathrm{C}$ and from 3.8 to $5.5 \mathrm{GPa}$, respectively, which was associated with growing percentage of the celadionite component $\left(\mathrm{KAl}\left(\mathrm{Mg}, \mathrm{Fe}^{2+}\right) \mathrm{Si}_{4} \mathrm{O}_{10}(\mathrm{OH})_{2}\right)$ and formation of kyanite. The run with pelite and mica schist produced a muscovite-garnet-omphacite-kyanite-coesite-rutile assemblage (Figure 1). Muscovite in the assemblage contained 3.52 apfu $\mathrm{Si}$ and thus was more strongly phengitized (had a higher percentage of celadionite) than that obtained in the muscovite-C-O-H-N system. Note that the phengite substitution line implies that $\mathrm{Si}^{\mathrm{IV}}$ and $\mathrm{Mg}^{\mathrm{VI}}$ substitute, respectively, for $\mathrm{Al}^{\mathrm{IV}}$ and $\mathrm{Al}^{\mathrm{VI}}[32,33]$. Garnet was mainly almandine or pyrope, and a considerable part was grossular; omphacite had 
a high percentage of jadeite. After the $6.3 \mathrm{GPa}$ and $1000^{\circ} \mathrm{C}$ run, mica schist consisted of almost the same muscovite-garnet-omphacite-kyanite-rutile assemblage but without coesite. The newly formed muscovite of this assemblage contained $3.49 \mathrm{apfu} \mathrm{Si}$ and was compositionally similar to that in the previous run. Garnet was more often almandine and less often grossular varieties; omphacite had a large jadeite component as well.

Table 3. Representative analyses of solid phases obtained in model muscovite-C-O-H-N system and with natural samples (wt. \%).

\begin{tabular}{|c|c|c|c|c|c|c|c|c|c|c|c|c|}
\hline Run\# & Phase & $\mathrm{SiO}_{2}$ & $\mathrm{TiO}_{2}$ & $\mathrm{Al}_{2} \mathrm{O}_{3}$ & $\mathrm{FeO}$ & $\mathrm{MnO}$ & $\mathrm{MgO}$ & $\mathrm{CaO}$ & $\mathrm{Na}_{2} \mathrm{O}$ & $\mathrm{K}_{2} \mathrm{O}$ & $\mathrm{BaO}$ & Total \\
\hline 1695_1_4 & Ms & 45.5 & 0.6 & 31.7 & 2.9 & - & 1.6 & - & 0.5 & 10.7 & 0.4 & 93.9 \\
\hline \multirow{2}{*}{ 1981_2_6 } & Ms & 47.6 & 0.2 & 29.5 & 3.1 & - & 1.7 & - & - & 11.3 & 0.5 & 93.8 \\
\hline & Ky & 36.6 & 0.0 & 63.5 & 0.3 & - & & - & - & & - & 100.4 \\
\hline \multirow{6}{*}{ 2093_2_1 } & Ms & 52.5 & 1.1 & 23.5 & 1.6 & - & 4.6 & - & - & 11.5 & - & 94.9 \\
\hline & Grt & 40.5 & 0.6 & 21.9 & 20.9 & 0.7 & 8.3 & 6.0 & - & - & - & 99.7 \\
\hline & Omp & 57.6 & 0.3 & 21.1 & 1.4 & - & 3.1 & 3.5 & 11.7 & - & - & 98.5 \\
\hline & Coe & 98.9 & - & - & - & - & - & - & - & - & - & 98.9 \\
\hline & Ky & 38.2 & - & 59.5 & 1.2 & - & - & - & - & - & - & 98.8 \\
\hline & $\mathrm{Ru}$ & 0.5 & 95.7 & 1.6 & 0.6 & - & - & - & - & - & - & 98.3 \\
\hline \multirow{5}{*}{ 2093_2_3 } & Ms & 52.3 & 1.1 & 24.5 & 2.5 & - & 4.2 & - & - & 10.7 & - & 95.3 \\
\hline & Grt & 38.1 & 0.2 & 21.2 & 29.5 & 0.5 & 9.4 & 0.6 & - & & - & 99.6 \\
\hline & Omp & 58.7 & 0.4 & 23.4 & 1.7 & 0.0 & 1.2 & 1.2 & 13.4 & 0.0 & - & 100.0 \\
\hline & $\mathrm{Ky}$ & 36.8 & 0.0 & 62.8 & 0.4 & - & - & - & - & - & - & 100.0 \\
\hline & $\mathrm{Ru}$ & 0.5 & 96.1 & 1.8 & 0.9 & - & - & - & - & - & - & 99.3 \\
\hline
\end{tabular}

$\mathrm{Ms}=$ muscovite, $\mathrm{Grt}=$ garnet, $\mathrm{Omp}=$ omphacite, $\mathrm{Ky}=$ kyanite, $\mathrm{Coe}=$ coesite, $\mathrm{Ru}=$ rutile.

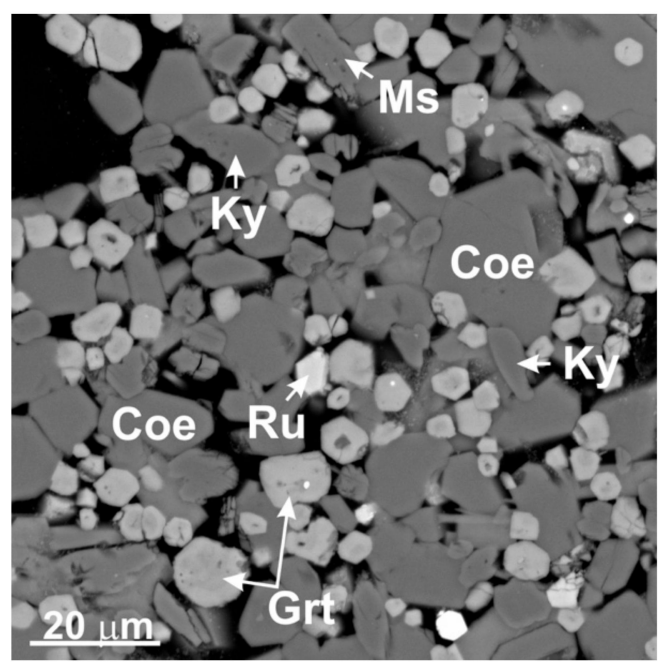

(a)

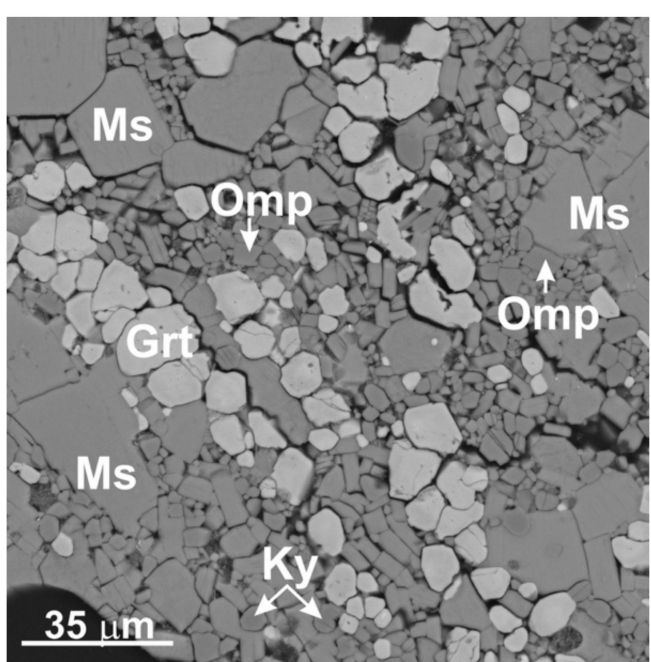

(b)

Figure 1. Microphotographs of pelite (a) and mica schist (b) samples after runs 2093_2_1 and 2093_2_3 at $6.3 \mathrm{GPa}$ and $1000{ }^{\circ} \mathrm{C}$. Abbreviations stand for names of minerals: Ms = muscovite, Grt = garnet, Omp = omphacite, $\mathrm{Ky}=$ kyanite, $\mathrm{Coe}=$ coesite, $\mathrm{Ru}=$ rutile.

According to GC-MS data, the quenched fluids contained light alkanes (Table 4, Figures 2 and 3) which formed by hydrogenation of graphite or diamond in most cases, except for two runs where docosane was used as a source of hydrocarbons (Table 1). Low-N fluids equilibrated in the C-O-H-N system at $f \mathrm{H}_{2}$ buffered by the $\mathrm{IW}+\mathrm{H}_{2} \mathrm{O}$ and $\mathrm{MMO}+\mathrm{H}_{2} \mathrm{O}$ equilibria contained 30 to 70 rel.\% alkanes (Table 4). The hydrogenation reaction stopped at $\mathrm{H}_{2} \mathrm{O}$ and $\mathrm{C}^{0}$ formation in a single run with $\mathrm{CO}_{2}$ added to the system, and the run products almost lacked light alkanes. The runs without external $\mathrm{H}_{2}$ buffering produced from 3 to 26 rel.\% of alkanes, mainly $\mathrm{C}_{1}-\mathrm{C}_{4}$ species, with high contents of $\mathrm{CH}_{4}$ and 
$\mathrm{C}_{2} \mathrm{H}_{6}$ but less than 10 rel.\% $\mathrm{C}_{3} \mathrm{H}_{8}$ and $\mathrm{C}_{4} \mathrm{H}_{10}$ (Figure 2), while $\mathrm{C}_{7}-\mathrm{C}_{18}$ were as low as $\leq 1$ rel.\%. Other species included notable amounts of aldehydes, ketones and carboxylic acids, the latter especially in non-buffered conditions with $\mathrm{CO}_{2}$ up to $11-43$ rel.\% (unlike $<3.6$ rel.\% in other runs).
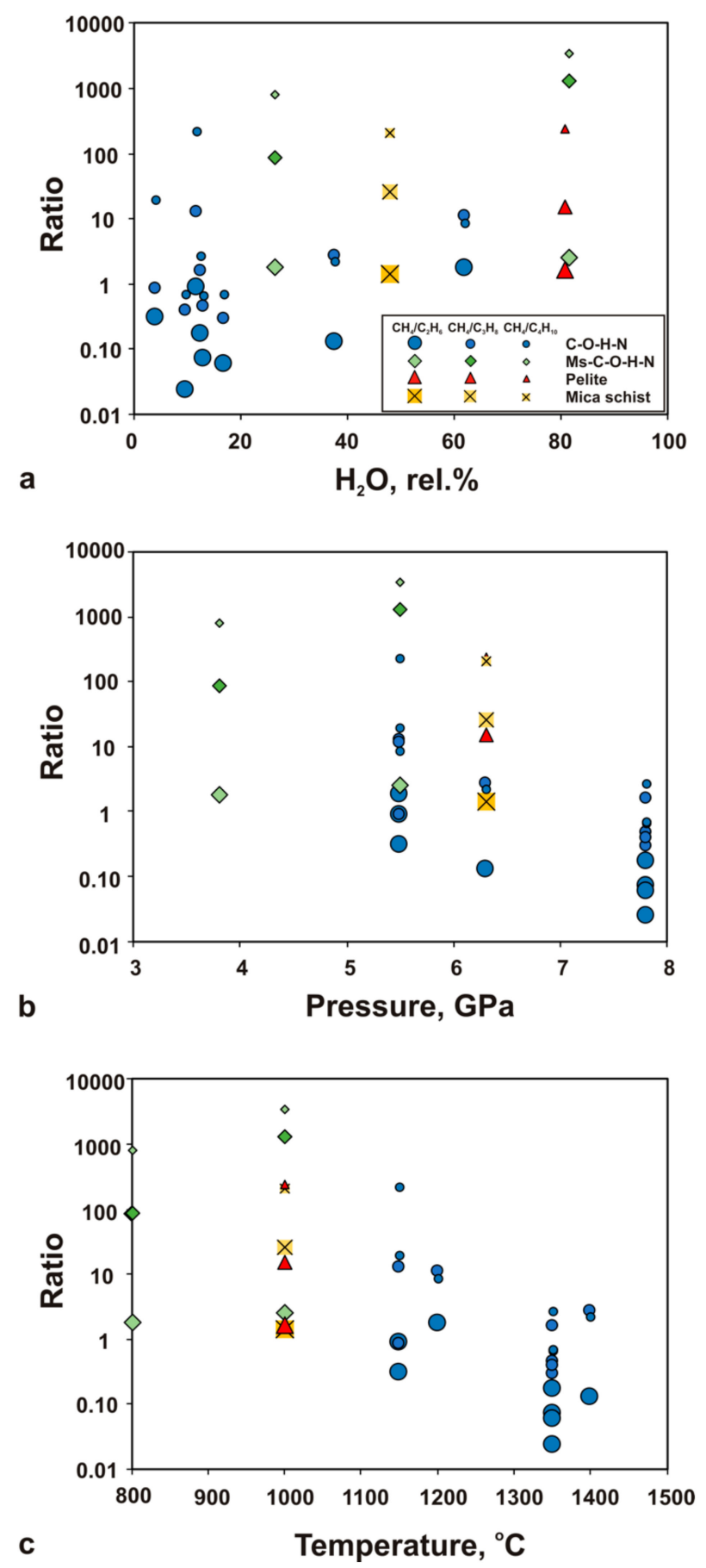

Figure 2. $\mathrm{CH}_{4} / \mathrm{C}_{2} \mathrm{H}_{6}, \mathrm{CH}_{4} / \mathrm{C}_{3} \mathrm{H}_{8}$, and $\mathrm{CH}_{4} / \mathrm{C}_{4} \mathrm{H}_{10}$ ratios in quenched fluids obtained in the $\mathrm{C}-\mathrm{O}-\mathrm{H}-\mathrm{N}$ and muscovite-C-O-H-N model systems and with natural samples, as a function of $\mathrm{H}_{2} \mathrm{O}$ content (a), pressure (b), and temperature (c). See the legend of $2 \mathrm{a}$ for $2 \mathrm{~b}$ and $2 \mathrm{c}$.

Hydrocarbon species appeared for the first time in the quenched fluids formed from the pelite and mica schist samples (Figure 3) at $6.3 \mathrm{GPa}, 100{ }^{\circ} \mathrm{C}$ and $f \mathrm{H}_{2}$ buffered by $\mathrm{MMO}+\mathrm{H}_{2} \mathrm{O}$, at the conditions that simulated subduction of these rocks in a slab to $\sim 200 \mathrm{~km}$ depths. Carbon in those charges could only come from carbonates which did not exceed a few wt. \% (Table 2). Dehydration of mica and 
reduction of carbonates led to water enrichment of the fluid, up to $48-81 \mathrm{rel} . \% \mathrm{H}_{2} \mathrm{O}$. The fluid contained predominant light HCs, from 15 to 39 rel.\%. The fluids synthesized from the charges with natural samples contained lighter alkanes than those obtained in the model $\mathrm{C}-\mathrm{O}-\mathrm{N}-\mathrm{H}$ system (Figures 2 and 3).

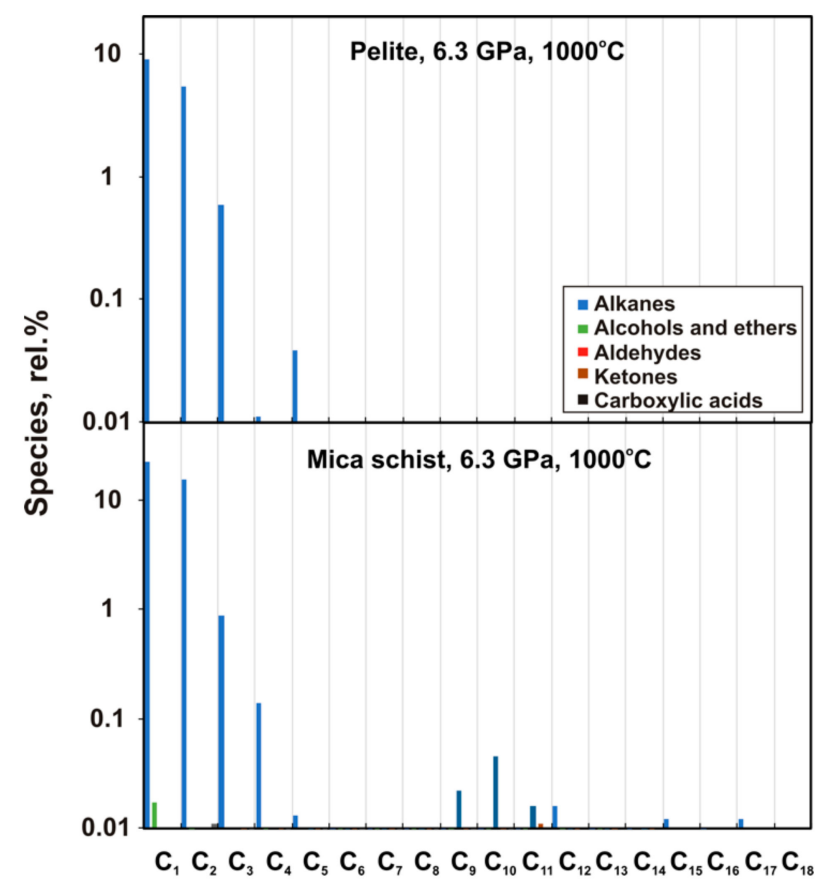

Figure 3. Speciation of hydrocarbons (HCs) in quenched fluids derived from natural samples, at $6.3 \mathrm{GPa}$ and $1000^{\circ} \mathrm{C}$.

Note that the fluids synthesized in the graphite-bearing muscovite- $\mathrm{C}-\mathrm{O}-\mathrm{H}-\mathrm{N}$ system likewise contained mainly light alkanes. As we showed before [18,19], heavier alkanes can form in experimental systems at higher pressures and temperatures, when Pt capsules are used instead of $\mathrm{Au}$ ones. Concentrations of heavier alkanes also become lower in fluids with lower $\mathrm{H}_{2} \mathrm{O}$ contents in the fluid [19]. Thus, the lighter alkane compositions obtained in the runs with the natural samples may be due to (1) a possible catalytic effect of solid matrix silicates (muscovite-garnet-omphacite-kyanite-rutile \pm coesite; (2) relatively low run temperature $\left(1000^{\circ} \mathrm{C}\right)$; (3) high water content in fluids (Figures 2 and 3), and (4) the use of $\mathrm{Au}$ capsules. These factors obviously controlled the composition of alkanes obtained in the muscovite-C-O-H-N system.

According to GC-MS data, $\mathrm{N}_{2}, \mathrm{NH}_{3}$ and $\mathrm{CH}_{3} \mathrm{~N}$ are main $\mathrm{N}$-bearing components of quenched fluids (Table 4, Figure 4). Their relative amounts depend on redox conditions, which were varied by either buffering or not the hydrogen fugacity in different runs. In the case of double capsule technique $f \mathrm{H}_{2}$ buffering, the redox conditions in the inner capsule increases with the water content within [47]. The concentration of $\mathrm{CO}_{2}$ measured by GC-MS is an informative parameter reflecting the growth of the fluid oxidation degree. $\mathrm{N}_{2}$ that was captured mainly from the air was a predominant nitrogen specie in the N-poor fluid synthesized in the $\mathrm{C}-\mathrm{O}-\mathrm{H}-\mathrm{N}$ system even at $\mathrm{CO}_{2}>1$ rel.\% (Figure 4a), but ammonia predominated at lower $\mathrm{CO}_{2}$ levels (Figure $4 \mathrm{~b}$ ). This trend is consistent with the fluid composition of the muscovite- $\mathrm{C}-\mathrm{O}-\mathrm{H}-\mathrm{N}$ system in the presence of an additional $\mathrm{N}$ source. Importantly, $\mathrm{CH}_{3} \mathrm{~N}$ (Table 4, Figure 4c) was the main nitrogen specie at low $\mathrm{CO}_{2}$ levels in the fluids that formed in systems with natural rock samples (nitrogen coming mostly from $\mathrm{NH}_{4}{ }^{+}$of clay minerals and muscovite), as well as in the model muscovite-C-O-H-N system (ambient air $\mathrm{N}$ ). 

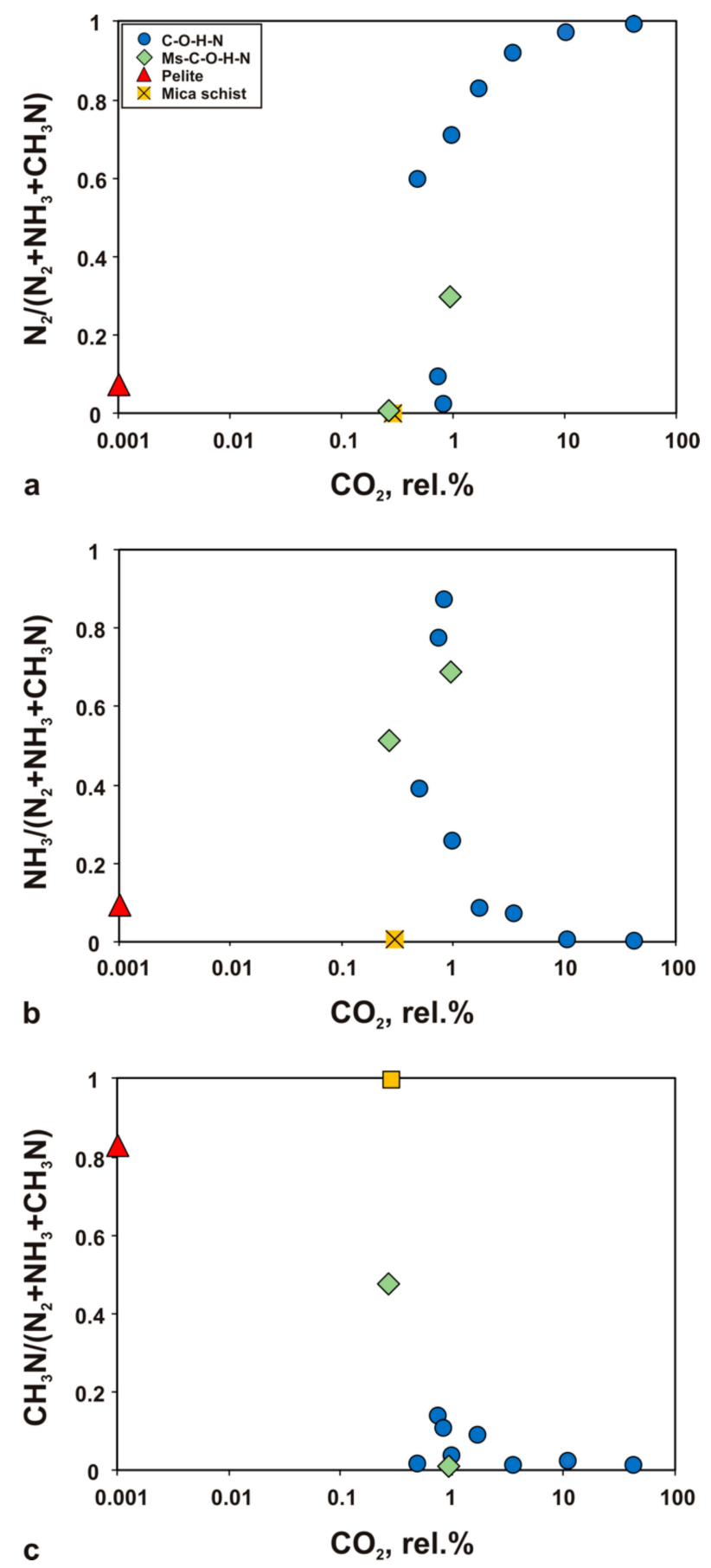

Figure 4. Relative contents of main nitrogen species $\left(\mathrm{N}_{2}, \mathrm{NH}_{3}\right.$ and $\left.\mathrm{CH}_{3} \mathrm{~N}\right)$ in quenched fluids obtained in the $\mathrm{C}-\mathrm{O}-\mathrm{H}-\mathrm{N}$ and muscovite- $\mathrm{C}-\mathrm{O}-\mathrm{H}-\mathrm{N}$ model systems and with natural samples, as a function of $\mathrm{CO}_{2}$ content: $\mathrm{N}_{2} /\left(\mathrm{N}_{2}+\mathrm{NH}_{3}+\mathrm{CH}_{3} \mathrm{~N}\right)(\mathbf{a}), \mathrm{NH}_{3} /\left(\mathrm{N}_{2}+\mathrm{NH}_{3}+\mathrm{CH}_{3} \mathrm{~N}\right)(\mathbf{b})$, and $\mathrm{CH}_{3} \mathrm{~N} /\left(\mathrm{N}_{2}+\mathrm{NH}_{3}+\right.$ $\left.\mathrm{CH}_{3} \mathrm{~N}\right)(\mathrm{c})$. See the legend of $4 \mathrm{a}$ for $4 \mathrm{~b}$ and $4 \mathrm{c}$.

High-resolution mass spectrometry was used to measure the exact molecular weight of the $29 \mathrm{Da}$ compound revealed by GC-MS. The measurements were made for quenched fluids obtained in $\mathrm{Au}$ capsules after runs 2007_2_3 and 2007_2_4 with model systems at $6.3 \mathrm{GPa}$ and $1200{ }^{\circ} \mathrm{C}$. The calculated mass for $\mathrm{CH}_{3} \mathrm{~N}[\mathrm{M}]^{+}$was 29.0260 , and the mass/charge ratio was $\mathrm{m} / \mathrm{z}=26.0250$. The closest mass is atmospheric $\left[{ }^{15} \mathrm{~N}^{14} \mathrm{~N}\right]^{+}$that has $\mathrm{m} / \mathrm{z}=29.0025$. GC-MS data obtained for gas mixtures in runs with high $\mathrm{CH}_{3} \mathrm{~N}$ contents (pelite and mica schist, Table 4) allowed detecting the mass spectrum more precisely. The mass spectrum we obtained (Figure 5) shows generally the same relative intensities of signals as 
the one published by Theule et al. [49], except for the presence of an $m / z=17$ signal, which remained cut off in the spectrum of Theule et al. [49], and for the absence of the $m / z=28$ signal possibly resulting from $\mathrm{N}_{2}$ pollution mentioned by the authors. Comparison of the $\mathrm{HCN}$ spectrum presented by Theule et al. [49] with the reference one from the NIST library (SRD 69) leads to the same inference since the spectrum by Theule et al. [49] has the heightened $\mathrm{m} / \mathrm{z}=28$ signal.

Table 4. Compositions of quenched fluids (rel.\%).

\begin{tabular}{ccccccccccc}
\hline Run \# & Alkanes & $\begin{array}{c}\text { Alcohols, } \\
\text { Ethers }\end{array}$ & Aldehydes & Ketones & $\begin{array}{c}\text { Carb. } \\
\text { Acids }\end{array}$ & $\mathbf{H}_{\mathbf{2}} \mathbf{O}$ & $\mathbf{C O}_{\mathbf{2}}$ & $\mathbf{N}_{\mathbf{2}}$ & $\mathbf{C H}_{\mathbf{3}} \mathbf{N}$ & $\mathbf{H}_{\mathbf{3}} \mathbf{N}$ \\
\hline 1668_2_1 & 3.9 & 3.3 & 15.2 & 5.3 & 1.6 & 4.1 & 42.9 & 17.7 & 0.2 & 0.0 \\
1906_2_1 & 26.6 & 0.4 & 1.7 & 0.6 & 16.9 & 37.5 & 10.7 & 4.3 & 0.1 & 0.0 \\
1969_2_1 & 69.9 & 1.2 & 2.5 & 2.2 & 1.9 & 11.7 & 0.8 & 0.6 & 0.9 & 5.1 \\
996_5_6 & 25.3 & 0.8 & 0.9 & 0.4 & 1.7 & 62.0 & 0.9 & 0.2 & 0.7 & 6.0 \\
1942_2_2* & 30.4 & 3.6 & 15.1 & 9.2 & 5.7 & 13.1 & 3.6 & 7.2 & 0.1 & 0.5 \\
1975_2_1 & 57.3 & 1.0 & 1.2 & 1.3 & 2.4 & 16.9 & 0.5 & 10.6 & 0.3 & 6.9 \\
1670_2_1 & 53.1 & 2.2 & 3.6 & 2.3 & 17.3 & 9.8 & 1.7 & 4.3 & 0.5 & 0.4 \\
1670_2_3 & 52.2 & 3.6 & 2.2 & 2.2 & 2.2 & 12.4 & 1.0 & 15.2 & 0.8 & 5.5 \\
1695_1_4 & 27.0 & 0.1 & 0.2 & 0.1 & 0.3 & 26.4 & 0.9 & 13.3 & 0.5 & 30.8 \\
1981_2_6 & 14.7 & 0.2 & 0.2 & 0.0 & 0.2 & 81.4 & 0.3 & 0.0 & 1.1 & 1.2 \\
2093_2_1 & 15.3 & 0.0 & 0.0 & 0.0 & 0.0 & 80.8 & 0.0 & 0.3 & 3.2 & 0.4 \\
2093_2_3 & 39.0 & 0.1 & 0.1 & 0.1 & 0.0 & 48.0 & 0.3 & 0.0 & 12.4 & 0.1 \\
\hline
\end{tabular}

* 6.8 rel. $\%$ olefins, 0.7 rel. $\%$ arenes, and 2.8 rel. $\%$ of other N-bearing species.

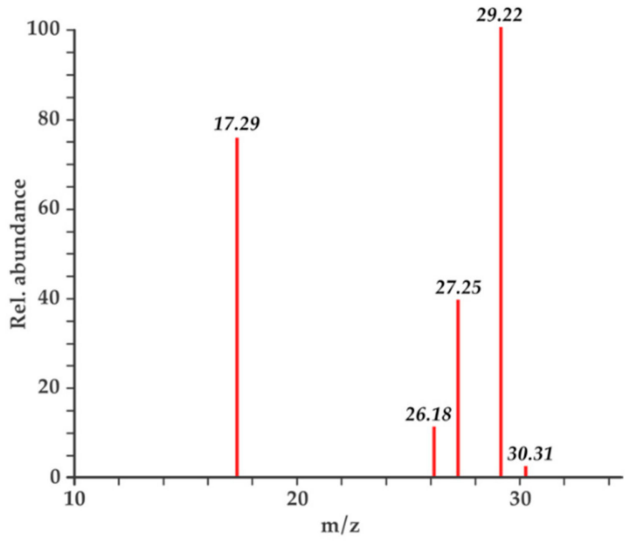

(a)

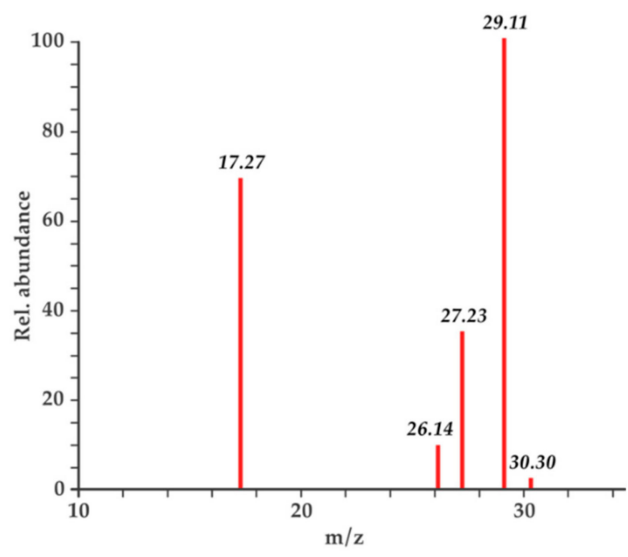

(b)

Figure 5. Mass spectra of the $\left[\mathrm{M}^{+}\right]=29$ compound of pelite (a) and mica schist (b) samples after runs 2093_2_1 and 2093_2_3 at $6.3 \mathrm{GPa}$ and $1000{ }^{\circ} \mathrm{C}$. The background is subtracted. Relative abundance units are \% of the most intensive signal.

\section{Discussion}

The reported experiments provide new knowledge on the composition of $\mathrm{C}$ - and $\mathrm{N}$-bearing species of reduced fluids obtained in the $\mathrm{C}-\mathrm{O}-\mathrm{H}-\mathrm{N}$ and muscovite- $\mathrm{C}-\mathrm{O}-\mathrm{H}-\mathrm{N}$ systems and from natural rock samples. As shown previously [10], $f \mathrm{O}_{2}$ may generally vary from $\log f \mathrm{O}_{2} \Delta \mathrm{IW}-2.5$ to $\log$ $f \mathrm{O}_{2} \Delta \mathrm{IW}+2.5$ depending on the initial $\mathrm{H}_{2} \mathrm{O}$ contents in the charge and the selected IW or MMO buffers for $f \mathrm{H}_{2}$. In the absence of external $f \mathrm{H}_{2}$ buffering, $f \mathrm{O}_{2}$ in the samples was slightly above IW $+2.5 \log$ units. The question is whether these redox conditions represent the conditions of slabs and the ambient mantle. Different serpentinization degrees of peridotite, involvement of variable amounts of carbonate in the slab material, and dehydration reactions during subduction can maintain heterogeneous redox conditions within slabs reaching depths of $150-350 \mathrm{~km}$ in a range of $6 \log$ units, from $\log f \mathrm{O}_{2} \Delta \mathrm{IW}-1$ to $\log f \mathrm{O}_{2} \Delta \mathrm{IW}+5$, while the surrounding mantle is generally more reduced $[50,51]$. Thus, the fluids we analyzed can form and remain stable only in the most reduced mantle and slab regions. 


\subsection{Carbon Species}

Carbon species in the quenched fluids from our experiments were mainly light alkanes $C_{1}-C_{4}$ (Table 4; Figure 2); $\mathrm{CO}_{2}$ reached considerable amounts in two runs with non-buffered $f \mathrm{H}_{2}$. In most of the runs, $\mathrm{HCs}$ formed by reactions of $\mathrm{H}_{2}-\mathrm{CO}_{2}-\mathrm{H}_{2} \mathrm{O}-\mathrm{N}_{2}$ fluids with carbon of graphite, while volatiles included $\mathrm{H}_{2}$ of the buffer and gases adsorbed on graphite particles of the starting material. The interaction of graphite with $\mathrm{H}_{2}$ discussed in detail in $[19,20]$ started with reduction of the adsorbed $\mathrm{CO}_{2}$, which however stopped in few minutes in the absence of other $\mathrm{CO}_{2}$ sources. No methanation of carbon dioxide can occur at $P-T$ parameters described. Hydrogenation of graphite produces tens of times more HC-bearing fluids than that of diamond. Graphite exfoliation by the fluid leads to significant increase in its surface area and to acceleration of the reaction [19].

In two runs, HCs formed mainly by thermal destruction of docosane at high pressures and temperatures, most likely by the mechanism of thermal cracking [10]. Decomposition of docosane appears to be the main process involving n-alkanes, including n-docosane and alkyl chains of fatty acids. In principle, the initial thermal formation of radical species of higher hydrocarbons in homolysis and rearrangement reactions leads to further $\beta$-scission into alkene and alkyl radicals with shorter chains [10]. Ethylene that forms in $\beta$-scission of terminal radicals in excess of $\mathrm{H}_{2}$ readily reduces to ethane. The radicals resulting from cracking can recombine or react with alkanes or alkenes to form new HC species and radicals.

The speciation of alkanes in quenched fluids (reference to Supplementary Table) is influenced by the experimental conditions. It was previously shown $[10,19,20]$ that in presence of Pt heavier $\mathrm{HCs}$ are formed due to the catalytic homologization $[52,53]$ mainly affecting the $\mathrm{CH}_{4} / \mathrm{C}_{2} \mathrm{H}_{6}$ ratio. This mechanism may also be responsible for the formation of minor amounts of branched or cyclic alkanes. Capsules of pure gold do not show major catalytic effects in the systems investigated, apparently due to the dissociation of hydrogen on the surface of neutral gold having energy barrier $[54,55]$, in contrast to Pt. Theoretical studies also showed that the adsorption of hydrocarbons, alkyl radicals and atomic $\mathrm{H}$ to the neutral $\mathrm{Au}^{0}$ appears to be disadvantageous [56]. On the other hand, the $\mathrm{H}_{2}$ permeability of $\mathrm{Au}$ is substantially lower that of $\mathrm{Pt}$, making the equilibrium to be attained slowly.

The runs with natural samples provided HC generation in strongly reduced conditions at the $P-T$ parameters simulating subduction to depths below $200 \mathrm{~km}$. The experiments actually reproduced metamorphic reactions, including partial dehydration of clay minerals and muscovite, which produced a muscovite-garnet-omphacite-kyanite-rutile \pm coesite matrix and a fluid, while the latter provided reduction of carbonates at $\mathrm{MMO}+\mathrm{H}_{2} \mathrm{O}$-buffered $f \mathrm{H}_{2}$. Reactions of this kind were earlier effectuated in simple model systems consisting of carbonate, $\mathrm{FeO}$ and $\mathrm{H}_{2} \mathrm{O}$ and yielded methane as a main product at high pressures and temperatures $[7,12,13,16,17,57]$. Methane formation in the reaction of $\mathrm{FeO}, \mathrm{CaCO}_{3}$, and $\mathrm{H}_{2} \mathrm{O}$ in experiments of Scott et al. [13] preferably occurred at temperatures below $1000{ }^{\circ} \mathrm{C}$ and pressures in a range of 5-11 GPa, and the yield of methane increased continuously as the temperature was elevated from 700 to $\sim 1200{ }^{\circ} \mathrm{C}$ at 4 to $5 \mathrm{GPa}$ in the experiments of Kenney et al. [12]. Unlike those results, the quenched fluids we obtained in the runs with the pelite samples at $6.3 \mathrm{GPa}$ and $1000^{\circ} \mathrm{C}$ contained commensurate amounts of methane and ethane and notably smaller amounts of other light alkanes (Figure 3). Our experiments differed by high $f \mathrm{H}_{2}$ which was constrained by oxidation of wüstite at the $\mathrm{WM}+\mathrm{H}_{2} \mathrm{O}$ equilibrium and exceeded that in the experiments with carbonate, $\mathrm{FeO}$ and $\mathrm{H}_{2} \mathrm{O}$. As we calculated [19], $f \mathrm{H}_{2}$ at the $\mathrm{MW}+\mathrm{H}_{2} \mathrm{O}$ equilibrium in this range of pressures and temperatures was 1.2-2.1 log units below the IW $+\mathrm{H}_{2} \mathrm{O}$ equilibrium. Since $f \mathrm{H}_{2}$ is the critical parameter governing HCs formation in these reactions [19,57], generation of light alkanes was faster in our case. The pelite sample contained much more carbonates and water than mica schist, and the respective quenched fluid had more water and less light alkanes: 81 rel. $\% \mathrm{H}_{2} \mathrm{O}$ and 15 rel.\% alkanes against $48 \mathrm{rel} . \% \mathrm{H}_{2} \mathrm{O}$ and 39 rel.\% alkanes in the case of mica schist.

Thus, our experiments reproduced three cases of HC generation under the upper mantle PT conditions: Thermal destruction of docosane; hydrogenation of graphite; hydrogenation of carbonates of pelites and products of their reduction. All reactions occurred at buffered $f \mathrm{H}_{2}$ produced mainly light 
alkanes, especially $\mathrm{CH}_{4}$ and $\mathrm{C}_{2} \mathrm{H}_{6}$ (Table 4; Figure 2). The muscovite-garnet-omphacite-kyanite-rutile \pm coesite assemblage did not influence much the composition of the generated HCs (Figure 3).

\subsection{N-Bearing Species}

The fluids synthesized in the N-poor $\mathrm{C}-\mathrm{O}-\mathrm{H}-\mathrm{N}$ system changed in predominant nitrogen species from $\mathrm{N}_{2}$ to $\mathrm{NH}_{3}$ as they became more reduced and depleted in $\mathrm{CO}_{2}$, whereas the respective change in the fluids obtained using natural samples was from $\mathrm{N}_{2}$ to $\mathrm{CH}_{3} \mathrm{~N}$ (Figure 4c). The identification of $\mathrm{CH}_{3} \mathrm{~N}$ by the conventional GC-MS routine was supplemented by the HR-MS analysis of a quenched fluid specially synthesized in the C-O-H-N system at $6.3 \mathrm{GPa}$ and $1200^{\circ} \mathrm{C}$. The $\mathrm{m} / \mathrm{z}=26.0250$ value obtained by HR-MS has provided solid support to the interpretation of the GC-MS data and a reference for detection of this species in fluids from other samples.

The limits of $\mathrm{NH}_{3}$ and $\mathrm{CH}_{3} \mathrm{~N}$ redox stability in the analyzed fluids generally coincide (Figure $4 \mathrm{~b}, \mathrm{c}$ ), and their contents increase rapidly as $\mathrm{CO}_{2}$ decreases to $<1$ rel.\%. Taking into account calculations of Stachel and Luth [58], the concentrations of $\mathrm{CO}_{2}$ about $1 \mathrm{rel} . \%$ in the $\mathrm{C}-\mathrm{O}-\mathrm{H}$ fluid can be estimated to represent the $\sim \mathrm{IW}+1 \log$ unit conditions. The fluids synthesized in our previous study [22] in the lherzolite-C-O-H-N system at $5.5-7.8 \mathrm{GPa}$ and $1150-1350^{\circ} \mathrm{C}$ and at $f \mathrm{O}_{2}$ from strongly reduced conditions (IW - $2.5 \mathrm{log}$. units) to the EMOD equilibrium contained ammonia as predominant nitrogen specie $\left(\mathrm{N}_{2} /\left(\mathrm{NH}_{3}+\mathrm{N}_{2}\right)=0.01-0.17\right)$ in the presence of metal-saturated lherzolite. However, the $\mathrm{N}_{2} /\left(\mathrm{NH}_{3}+\mathrm{N}_{2}\right)$ ratio approached unity in the presence of magnesite-bearing lherzolite, i.e., at more oxidized conditions. In the same way, the reported experiments show the concentration of ammonia decreasing rapidly once $\mathrm{CO}_{2}$ in the fluid from the lherzolite-C-O-H-N system exceeded 1 rel.\% (Figure $4 \mathrm{~b})$. The concentration of methanimine $\left(\mathrm{CH}_{3} \mathrm{~N}\right)$ in the reduced fluid is controlled by the ratio of nitrogen to active $\mathrm{C}$-bearing precursors of $\mathrm{CH}_{3} \mathrm{~N}$ in the system, the content of precursors being substantially higher in the systems containing pelitic rocks. The exact mechanism was not investigated so far. In the presence of melamine in the starting composition, $\mathrm{NH}_{3}$ predominated over $\mathrm{CH}_{3} \mathrm{~N}$ over the whole range of applied $f \mathrm{O}_{2}$, in the case of both metal- and magnesite-saturated lherzolites. The concentrations of $\mathrm{NH}_{3}$ and $\mathrm{CH}_{3} \mathrm{~N}$ remained comparable in $\mathrm{N}$-poor fluids where atmospheric $\mathrm{N}_{2}$ was the only source of nitrogen. Note that most of nitrogen in the fluids obtained in equilibrium with the pelitic mineral assemblage came from $\mathrm{NH}_{4}{ }^{+}$in clay minerals and micas, and $\mathrm{CH}_{3} \mathrm{~N}$ was the dominant nitrogen species of reduced fluids in that case.

The new experimental results confirm the common trend of $\mathrm{NH}_{3}$ stability in fluids of the model systems at 3.8 to $7.8 \mathrm{GPa}$ and 800 to $1400{ }^{\circ} \mathrm{C}$, in the upper mantle redox conditions. Therefore, considerable amounts of ammonia may be present in a fluid stable either in a relatively cold reduced lithosphere or in a metal-saturated asthenosphere. This study has provided the first evidence that methanimine $\left(\mathrm{CH}_{3} \mathrm{~N}\right)$ may be an essential N-bearing specie in the reduced fluid obtained from natural pelite samples in the $P-T$ conditions of $6.3 \mathrm{GPa}$ and $1000{ }^{\circ} \mathrm{C}$ corresponding to a hot slab subducted to $200 \mathrm{~km}$. The ammonia concentration controls the solubility of nitrogen in K-bearing silicates since $\mathrm{NH}_{4}{ }^{+}$can partially replace $\mathrm{K}^{+}[3,30]$. On the other hand, the basicity of $\mathrm{CH}_{3} \mathrm{~N}$ and the big size of methanimine cation $\mathrm{CH}_{3} \mathrm{NH}^{+}$prevent the replacement of $\mathrm{K}^{+}$in silicates. Thus, the stability of $\mathrm{CH}_{3} \mathrm{~N}$ in reduced fluids may substantially influence the mantle cycle of nitrogen because methanimine cannot incorporate into silicates (like $\mathrm{NH}_{4}{ }^{+} \rightarrow \mathrm{K}^{+}$substitutions), which limits the solubility of $\mathrm{N}$ in silicates at low $f \mathrm{O}_{2}$.

\section{Conclusions}

Our experiments at the upper mantle $P-T$ conditions reproduced three potentially important ways of HC generation: (i) Thermal desctruction of docosane; (ii) hydrogenation of graphite; (iii) hydrogenation of pelitic carbonates or products of their reduction. The aforementioned processes conducted under $f \mathrm{H}_{2}$ buffering produced mainly light alkanes, especially methane and ethane revealed by the GC-MS analysis of the quenched fluids. The alkanes became heavier upon pressure and temperature increase from 3.8 to $7.8 \mathrm{GPa}$ and from 800 to $1400{ }^{\circ} \mathrm{C}$. The quenched 
fluids obtained at unbuffered $f \mathrm{H}_{2}$ contained $>10$ rel.\% $\mathrm{CO}_{2}$, lesser amounts of alkanes but more O-bearing organic compounds. The fluids produced by partial dehydration of hydrous minerals or by hydrogenation of carbonates (or their reduction products) in equilibrium with the muscovite-garnet-omphacite-kyanite-rutile \pm coesite assemblage consisted of $50-80 \mathrm{rel} . \% \mathrm{H}_{2} \mathrm{O}$ and 15-40 rel.\% alkanes $\left(\mathrm{C}_{1}>\mathrm{C}_{2}>\mathrm{C}_{3}>\mathrm{C}_{4}\right)$. Therefore, subduction of $\mathrm{H}_{2} \mathrm{O}$ - and carbonate-bearing clayey sediments into strongly reduced mantle below $200 \mathrm{~km}$, where $f \mathrm{O}_{2}$ is as low as the IW buffer, can be expected to induce generation of light alkanes. The HCs generated in slabs may form a hydrocarbon link in the deep cycles of carbon and hydrogen.

The dominant nitrogen specie in the quenched fluids synthesized in the simplified C-O-H-N system, where nitrogen comes from air or melamine, changes from $\mathrm{N}_{2}$ to $\mathrm{NH}_{3}$ as the system becomes more reduced. The respective change in the fluids obtained from natural samples, with $\mathrm{NH}_{4}{ }^{+}$as the carbon source, is from $\mathrm{N}_{2}$ to mainly $\mathrm{CH}_{3} \mathrm{~N}$. The concentration of $\mathrm{CH}_{3} \mathrm{~N}$ in the reduced fluid increases at higher ratio of $\mathrm{C}$-bearing precursors to bulk nitrogen in the system. The presence of $\mathrm{CH}_{3} \mathrm{~N}$ in the quenched fluid derived from the $\mathrm{C}-\mathrm{O}-\mathrm{H}-\mathrm{N}$ system has been checked by high resolution mass-spectrometry. The $\mathrm{CH}_{3} \mathrm{NH}^{+}$ion, being much bigger than $\mathrm{NH}_{4}{ }^{+}$, cannot substitute for $\mathrm{K}^{+}$in $\mathrm{K}$-bearing silicates. Therefore, the stability of $\mathrm{CH}_{3} \mathrm{~N}$ in reduced $\mathrm{N}$-poor fluids may limit the solubility of $\mathrm{N}$ in silicates at low $f \mathrm{O}_{2}$ and thus influence considerably the mantle cycle of nitrogen.

Supplementary Materials: The following are available online at http://www.mdpi.com/2075-163X/9/11/712/s1.

Author Contributions: Conceptualization, A.S., I.S. and T.B.; Formal analysis, T.B., A.T. and A.N.; Investigation, I.S., A.S., P.Z. and T.B.; Methodology, A.S., A.T., A.N. and I.S.; Supervision, I.S. and A.S.; Writing-original draft, A.S. and I.S.; Writing-review and editing, A.S. and I.S.

Funding: The study was supported by grant 16-17-10041 from the Russian Science Foundation. Experiments with the muscovite-C-O-H-N system were performed as part of a government assignment to the V.S. Sobolev Institute of Geology and Mineralogy (Novosibirsk).

Acknowledgments: We wish to thank Yuri Palyanov and Yuri Borzdov for their assistance throughout the study.

Conflicts of Interest: The authors declare no conflict of interest.

\section{References}

1. Etiope, G.; Sherwood Lollar, B. Abiotic methane on Earth. Rev. Geophys. 2013, 51, 276-299. [CrossRef]

2. Palyanov, Y.N.; Bataleva, Y.V.; Sokol, A.G.; Borzdov, Y.M.; Kupriyanov, I.N.; Reutsky, V.N.; Sobolev, N.V. Mantle-slab interaction and redox mechanism of diamond formation. Proc. Natl. Acad. Sci. USA 2013, 110, 20408-20413. [CrossRef] [PubMed]

3. Luth, R.W. Volatiles in Earth's mantle. In Treatise on Geochemistry, 2nd ed.; Elsevier: Oxford, UK, 2014; Volume 3, pp. 355-391.

4. Sverjensky, D.A.; Stagno, V.; Huang, F. Important role for organic carbon in subduction-zone fluids in the deep carbon cycle. Nat. Geosci. 2014, 7, 909. [CrossRef]

5. Smith, E.M.; Shirey, S.B.; Nestola, F.; Bullock, E.S.; Wang, J.; Richardson, S.H.; Wang, W. Large gem diamonds from metallic liquid in Earth's deep mantle. Science 2016, 354, 1403-1405. [CrossRef]

6. Bebout, G.E.; Lazzeri, K.E.; Geiger, C.A. Pathways for nitrogen cycling in Earth's crust and upper mantle: A review and new results for microporous beryl and cordierite. Am. Mineral. 2016, 101, 7-24. [CrossRef]

7. Kolesnikov, A.Y.; Saul, J.M.; Kutcherov, V.G. Chemistry of hydrocarbons under extreme thermobaric conditions. ChemistrySelect 2017, 2, 1336-1352. [CrossRef]

8. Matveev, S.; Ballhaus, C.; Fricke, K.; Truckenbrodt, J.; Ziegenben, D. Volatiles in the Earth's mantle: I. Synthesis of CHO fluids at $1273 \mathrm{~K}$ and $2.4 \mathrm{GPa}$. Geochim. Cosmochim. Acta 1997, 61, 3081-3088. [CrossRef]

9. Sokol, A.G.; Palyanova, G.A.; Palyanov, Y.N.; Tomilenko, A.A.; Melenevsky, V.N. Fluid regime and diamond formation in the reduced mantle: Experimental constraints. Geochim. Cosmochim. Acta 2009, 73, 5820-5834. [CrossRef]

10. Sokol, A.G.; Tomilenko, A.A.; Bul'bak, T.A.; Palyanova, G.A.; Sokol, I.A.; Palyanov, Y.N. Carbon and Nitrogen Speciation in N-poor C-O-H-N Fluids at 6.3 GPa and 1100-1400 ${ }^{\circ}$ C. Sci. Rep. 2017, 7, 706. [CrossRef] 
11. Matjuschkin, V.; Woodland, A.B.; Yaxley, G.M. Methane-bearing fluids in the upper mantle: An experimental approach. Contrib. Mineral. Petrol. 2019, 174, 1. [CrossRef]

12. Kenney, J.F.; Kutcherov, V.A.; Bendeliani, N.A.; Alekseev, V.A. The evolution of multicomponent systems at high pressures: The thermodynamic stability of the hydrogen-carbon system: The genesis of hydrocarbons and the origin of petroleum. Proc. Nat. Acad. Sci. USA 2002, 99, 10976-10981. [CrossRef] [PubMed]

13. Scott, H.P.; Hemley, R.J.; Mao, H.; Herschbach, D.R.; Fried, L.E.; Howard, W.M.; Bastea, S. Generation of methane in the Earth's mantle: In situ high pressure-temperature measurements of carbonate reduction. Proc. Nat. Acad. Sci. USA 2004, 101, 14023-14026. [CrossRef] [PubMed]

14. Kutcherov, V.G.; Kolesnikov, A.Y.; Dyuzheva, T.I.; Kulikova, L.F.; Nikolaev, N.N.; Sazanova, O.A.; Braghkin, V.V. Synthesis of Complex Hydrocarbon Systems at Temperatures and Pressures Corresponding to the Earth's Upper Mantle Conditions. Dokl. Phys. Chem. 2010, 433, 132-135. [CrossRef]

15. Palyanov, Y.N.; Borzdov, Y.M.; Kupriyanov, I.N.; Khokhryakov, A.F. Effect of $\mathrm{H}_{2} \mathrm{O}$ on diamond crystal growth in metal-carbon systems. Cryst. Growth Des. 2010, 12, 5571-5578. [CrossRef]

16. Mukhina, E.; Kolesnikov, A.; Kutcherov, V. The lower pT limit of deep hydrocarbon synthesis by $\mathrm{CaCO}_{3}$ aqueous reduction. Sci. Rep. 2017, 7, 5749. [CrossRef] [PubMed]

17. Tao, R.; Zhang, L.; Tian, M.; Zhu, J.; Liu, X.; Liu, J.; Höfer, H.E.; Stagno, V.; Fei, Y. Formation of abiotic hydrocarbon from reduction of carbonate in subduction zones: Constraints from petrological observation and experimental simulation. Geochim. Cosmochim. Acta 2018, 239, 390-408. [CrossRef]

18. Sokol, A.G.; Tomilenko, A.A.; Bul'bak, T.A.; Sokol, I.A.; Persikov, E.S.; Bukhtiyarov, P.G.; Palyanov, Y.N. Distribution of light alkanes in the reaction of graphite hydrogenation at pressure of 0.1-7.8 GPa and temperatures of $1000-1350{ }^{\circ} \mathrm{C}$. High Press. Res. 2018, 38, 468-481. [CrossRef]

19. Sokol, A.G.; Tomilenko, A.A.; Bul’bak, T.A.; Sokol, I.A.; Zaikin, P.A.; Palyanova, G.A.; Palyanov, Y.N. Hydrogenation of carbon at 5.5-7.8 GPa and $1100-1400^{\circ} \mathrm{C}$ : Implications to formation of hydrocarbons in reduced mantles of terrestrial planets. Phys. Earth Planet. Inter. 2019, 291, 12-23. [CrossRef]

20. Sokol, A.; Tomilenko, A.; Sokol, I.; Zaikin, P.; Bul'bak, T. Formation of Hydrocarbons in the Presence of Native Iron at Upper Mantle Conditions: Experimental Constraints. Minerals 2019, in press.

21. Mikhail, S.; Sverjensky, D.A. Nitrogen speciation in upper mantle fluids and the origin of Earth's nitrogen-rich atmosphere. Nat. Geosci. 2014, 7, 816-819. [CrossRef]

22. Sokol, A.G.; Tomilenko, A.A.; Bul'bak, T.A.; Kruk, A.N.; Sokol, I.A.; Palyanov, Y.N. Fate of fluids at the base of subcratonic lithosphere: Experimental constraints at 5.5-7.8 GPa and 1150-1350 deg C. Lithos 2018, 318, 419-433. [CrossRef]

23. Chukanov, N.V.; Pekov, I.V.; Sokolov, S.V.; Nekrasov, A.N.; Chukanova, V.N.; Naumova, I.S. On the problem of the formation and geochemical role of bituminous matter in pegmatites of the Khibiny and Lovozero alkaline massifs, Kola Peninsula, Russia. Geochem. Int. 2006, 44, 715-728. [CrossRef]

24. Smith, E.M.; Shirey, S.B.; Richardson, S.H.; Nestola, F.; Bullock, E.S.; Wang, J.; Wang, W. Blue boron-bearing diamonds from Earth's lower mantle. Nature 2018, 560, 84. [CrossRef] [PubMed]

25. Sobolev, N.V.; Sobolev, A.V.; Tomilenko, A.A.; Kuz'min, D.V.; Grakhanov, S.A.; Batanova, V.G.; Logvinova, A.M.; Bul'bak, T.A.; Kostrovitskii, S.I.; Yakovlev, D.A.; et al. Prospects of search for diamondiferous kimberlites in the northeastern Siberian. Platform. Russ. Geol. Geophys. 2018, 59, 1365-1379. [CrossRef]

26. Sobolev, N.V.; Tomilenko, A.A.; Bul'bak, T.A.; Logvinova, A.M. Composition of volatile components in the diamonds, associated garnet and olivine from diamondiferous peridotites from the Udachnaya pipe, Yakutia, Russia (by coupled gas chromatographic-mass spectrometric analysis). Engineering 2019, 5, 471-478. [CrossRef]

27. Sobolev, N.V.; Logvinova, A.M.; Tomilenko, A.A.; Wirth, R.; Bul'bak, T.A.; Luk'yanova, L.I.; Fedorova, E.N.; Reutsky, V.N.; Efimova, E.S. Mineral and fluid inclusions in diamonds from the Urals placers, Russia: Evidence for solid molecular $\mathrm{N}_{2}$ and hydrocarbons in fluid inclusions. Geochim. Cosmochim. Acta 2019, 266, 197-219. [CrossRef]

28. Plank, T.; Langmuir, C.H. The chemical composition of subducting sediment and its consequences for the crust and mantle. Chem. Geol. 1998, 145, 325-394. [CrossRef]

29. Schmidt, M.; Poli, S. Devolatilization during subduction. In Treatise on Geochemistry, 2nd ed.; Elsevier: Oxford, UK, 2014; pp. 669-701.

30. Watenphul, A.; Wunder, B.; Heinrich, W. High-pressure ammonium-bearing silicates: Implications for nitrogen and hydrogen storage in the Earth's mantle. Am. Mineral. 2009, 94, 283-292. [CrossRef] 
31. Watenphul, A.; Wunder, B.; Wirth, R.; Heinrich, W. Ammonium-bearing clinopyroxene: A potential nitrogen reservoir in the Earth's mantle. Chem. Geol. 2010, 270, 240-248. [CrossRef]

32. Domanik, K.J.; Holloway, J.R. The stability and composition of phengitic muscovite and associated phases from 5.5 to 11 GPa: Implications for deeply subducted sediments. Geochim. Cosmochim. Acta 1996, 60, 4133-4150. [CrossRef]

33. Schmidt, M.W.; Vielzeuf, D.; Auzanneau, E. Melting and dissolution of subducting crust at high pressurfufes: The key role of white mica. Earth Planet. Sci. Lett. 2004, 228, 65-84. [CrossRef]

34. Busigny, V.; Cartigny, P.; Philippot, P.; Ader, M.; Javoy, M. Massive recycling of nitrogen and other fluid-mobile elements $(\mathrm{K}, \mathrm{Rb}, \mathrm{Cs}, \mathrm{H})$ in a cold slab environment: Evidence from HP to UHP oceanic metasediments of the Schistes Lustrés nappe (western Alps, Europe). Earth Planet. Sci. Lett. 2003, 215, 27-42. [CrossRef]

35. Cartigny, P.; Harris, J.W.; Javoy, M. Diamond genesis, mantle fractionations and mantle nitrogen content: A study of $\delta^{13} \mathrm{C}-\mathrm{N}$ concentrations in diamonds. Earth Planet. Sci. Lett. 2001, 185, 85-98. [CrossRef]

36. Li, Y.; Keppler, H. Nitrogen speciation in mantle and crustal fluids. Geochim. Cosmochim. Acta 2014, 129, 13-32. [CrossRef]

37. Sokol, A.G.; Tomilenko, A.A.; Bul'bak, T.A.; Kruk, A.N.; Zaikin, P.A.; Sokol, I.A.; Seryotkin, Y.V.; Palyanov, Y.N. The Fe-C-O-H-N system at 6.3-7.8 GPa and 1200-1400 ${ }^{\circ} \mathrm{C}$ : Implications for deep carbon and nitrogen cycles. Contrib. Mineral. Petrol. 2018, 173, 47. [CrossRef]

38. Sokol, A.G.; Palyanov, Y.N.; Tomilenko, A.A.; Bul'bak, T.A.; Palyanova, G.A. Carbon and nitrogen speciation in nitrogen-rich C-O-H-N fluids at 5.5-7.8 GPa. Earth Planet. Sci. Lett. 2017, 460, 234-243. [CrossRef]

39. Sokol, E.; Kokh, S.; Kozmenko, O.; Novikova, S.; Khvorov, P.; Nigmatulina, E.; Belogub, E.; Kirillov, M. Mineralogy and Geochemistry of Mud Volcanic Ejecta: A New Look at Old Issues (A Case Study from the Bulganak Field, Northern Black Sea). Minerals 2018, 8, 344. [CrossRef]

40. Karpenko, V.Y.; Pautov, L.A.; Agakhanov, A.A.; Khvorov, P.V. On Nitrogen Content in the Schist of the Mun'-Khambo Ridge (N. Ural); The Ural Mineralogical Collected Papers \#11. Scientific Edition; Institute of Mineralogy, Ural Branch of Russian Academy of Sciences: Miass, Russia, 2001; p. 330.

41. Li, L.; Bebout, G.E. Carbon and nitrogen geochemistry of sediments in the Central American convergent margin: Insights regarding subduction input fluxes, diagenesis, and paleoproductivity. J. Geophys. Res. Solid Earth 2005, 110, B11202. [CrossRef]

42. Busigny, V.; Cartigny, P.; Philippot, P. Nitrogen isotopes in ophiolitic metagabbros: A re-evaluation of modern nitrogen fluxes in subduction zones and implication for the early Earth atmosphere. Geochim. Cosmochim. Acta 2011, 75, 7502-7521. [CrossRef]

43. Bebout, G.E.; Agard, P.; Kobayashi, K.; Moriguti, T.; Nakamura, E. Devolatilization history and trace element mobility in deeply subducted sedimentary rocks: Evidence from Western Alps HP/UHP suites. Chem. Geol. 2013, 342, 1-20. [CrossRef]

44. Busigny, V.; Bebout, G.E. Nitrogen in the silicate Earth: Speciation and isotopic behavior during mineral-fluid interactions. Elements 2013, 9, 353-358. [CrossRef]

45. Palyanov, Y.N.; Borzdov, Y.M.; Khokhryakov, A.F.; Kupriyanov, I.N.; Sokol, A.G. Effect of nitrogen impurity on diamond crystal growth processes. Cryst. Growth Des. 2010, 10, 3169-3175. [CrossRef]

46. Sokol, A.G.; Borzdov, Y.M.; Palyanov, Y.N.; Khokhryakov, A.F. High-temperature calibration of a multi-anvil high-pressure apparatus. High Press. Res. 2015, 35, 139-147. [CrossRef]

47. Luth, R.W. Natural versus experimental control of oxidation state: Effects on the composition and speciation of C-O-H fluids. Am. Mineral. 1989, 74, 50-57.

48. Dementyev, S.N.; Drebushchak, V.A. Zeolites' dehydration under dynamic regime. Geochem. Int. 1992, 9 , 1361-1367.

49. Theule, P.; Borget, F.; Mispelaer, F.; Danger, G.; Duvernay, F.; Guillemin, J.C.; Chiavassa, T. Hydrogenation of solid hydrogen cyanide $\mathrm{HCN}$ and methanimine $\mathrm{CH}_{2} \mathrm{NH}$ at low temperature. Astron. Astrophys. 2011, 534, A64. [CrossRef]

50. Foley, S. A reappraisal of redox melting in the Earth's mantle as a function of tectonic setting and time. J. Petrol. 2011, 52, 1363-1391. [CrossRef]

51. Stagno, V.; Ojwang, D.O.; McCammon, C.A.; Frost, D.J. The oxidation state of the mantle and the extraction of carbon from Earth's interior. Nature 2013, 493, 84. [CrossRef]

52. Robertson, A.J.B. The Pyrolysis of Methane, Ethane and n-butane on a Platinum Filament. Proc. R. Soc. Lond. A Math. Phys. Eng. Sci. 1949, 199, 394. 
53. Belgued, M.; Amariglio, A.; Paréja, P.; Amariglio, H. Oxygen-Free conversion of methane to higher alkanes through an isothermal two-step reaction on platinum (EUROPT-1): II. hydrogenation of the adspecies resulting from the chemisorption of methane. J. Catal. 1996, 159, 449-457. [CrossRef]

54. Hammer, B.; Nørskov, J. Why gold is the noblest of all the metals. Nature 1995, 376, 238. [CrossRef]

55. McEwan, L.; Julius, M.; Roberts, S.; Fletcher, J.C.Q. A review of the use of gold catalysts in selective hydrogenation reactions. Gold Bull. 2010, 43, 298.

56. Mowbray, D.J.; Migani, A.; Walther, G.; Cardamone, D.M.; Rubio, A. Gold and methane: A noble combination for delicate oxidation. J. Phys. Chem. Lett. 2013, 4, 3006-3012. [CrossRef]

57. Sharma, A.; Cody, G.D.; Hemley, R.J. In situ diamond-anvil cell observations of methanogenesis at high pressures and temperatures. Energy Fuels 2009, 23, 5571-5579. [CrossRef]

58. Stachel, T.; Luth, R.W. Diamond formation-Where, when and how? Lithos 2015, 220, 200-220. [CrossRef]

(C) 2019 by the authors. Licensee MDPI, Basel, Switzerland. This article is an open access article distributed under the terms and conditions of the Creative Commons Attribution (CC BY) license (http://creativecommons.org/licenses/by/4.0/). 